2.

\title{
THE TINY ANIMAL AT THE CENTRE OF
} THE MARINE ECOSYSTEM

PROFESSOR MARC FRISCHER FROM THE UNIVERSITY OF GEORGIA'S SKIDAWAY INSTITUTE OF OCEANOGRAPHY IS INVESTIGATING TINY OCEAN CREATURES KNOWN AS DOLIOLIDS AND THE FOOD THEY EAT. WHY? HIS RESEARCH CAN HELP US UNDERSTAND THEIR ROLE IN OCEAN FOOD WEBS AND THE IMPACT CLIMATE CHANGE COULD CAUSE

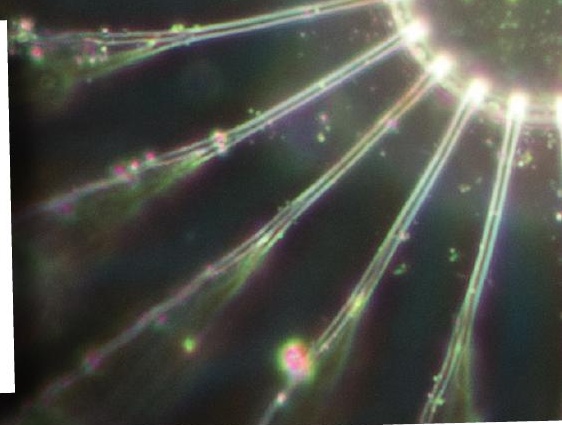

\section{WHO'S EATINE WHAT IN AN OCEAN FOOD WEB?}

Phytoplankton use energy from sunlight and nutrients dissolved in the water, to convert $\mathrm{CO}_{2}$ to organic carbon. This forms the base of the marine food web - the cycling of matter and energy.

Phytoplankton are eaten by microzooplankton and zooplankton, which provide a food source for fish, which in turn feed the larger predators, such as squid and sharks. Nutrients associated with phytoplankton that are not consumed by larger organisms are decomposed by bacteria.

Most of the carbon is converted back into $\mathrm{CO}_{2}$ and released into the atmosphere, but some is transported into the deep ocean, where it can be stored for hundreds to thousands of years.

The structure of the food web, and the abundance of each species will control how much carbon is transported to the deep ocean.

\section{Figure modified from Chisholm, S.W. (2000). Stirring} times in the Southern Ocean. Nature. 407, 685-687. times in the Southern Oceon.
doi: $10.1038 / 35037696$

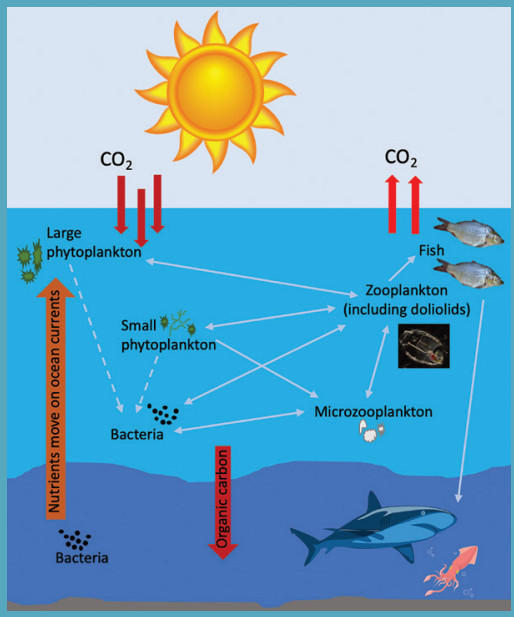

Most people have never heard of, let alone seen, a doliolid, but these tiny creatures play a critical role in the marine ecosystem. So much so, that Marc Frischer, a professor from the University of Georgia's Skidaway Institute of Oceanography, and his team are investigating them, their eating habits and the role they play in ocean food webs.

Ranging in size between one and 15 millimetres (depending on the stage of their complex life cycle), doliolids are small, transparent, and barrel-shaped. These gelatinous marine animals live on the continental shelves all over the world. Continental shelves are the shallow parts of the ocean that surround the continents and are some of the most productive regions of the ocean. Even though continental shelves only occupy $7-8 \%$ of the ocean area, half of all ocean productivity when plants and bacteria produce energy for the rest of the ecosystem to use - occurs here.

Doliolids are a type of zooplankton, a group of small animals that drift around in the water. Although most zooplankton are tiny, there are so many of them that by weight they're the most abundant type of animal in the ocean.

\section{WHY IS IT SO IMPORTANT}

TO STUDY DOLIOLIDS?

Marc studies doliolids because they eat microbes. Microbes are tiny life forms, including bacteria, phytoplankton, viruses, and fungi, that surround us everywhere. Without them, we wouldn't be around to study them. "I've always been interested in figuring out how microbial communities in oceans interact with larger organisms as well as the planetary-scale cycling of matter and energy, all of which helps to maintain balance in our marine ecosystem," says Marc.

Doliolids are particularly fascinating because their numbers vary greatly. Sometimes there's
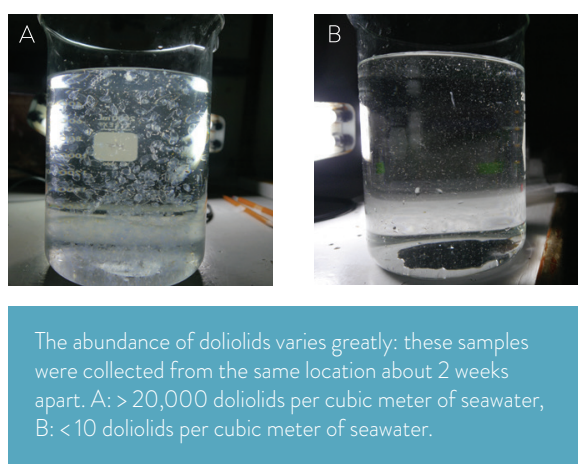

an abundance of them; at other times there are hardly any (see above). Because these changes in the doliolid population are unpredictable, their impact on the ecosystem's food web is complicated and difficult to understand.

Because doliolids can be so abundant in productive continental shelf environments, understanding what they eat, how much they eat and ultimately who eats them would provide some hints on how they're involved in balancing the marine ecosystem.

\section{IF WE KNOW DOLIOLIDS EAT}

MICROBES, WHY IS MARC

STUDYING THEIR DIET?

It's known that doliolids are able to eat algae, other microbes and small zooplankton that fit in their mouths, which means their eating habits have a large impact on life in the ocean. But because doliolids are so small and fragile, it's very hard to study them. As a result, scientists aren't exactly sure what and how much they eat.

Microbes dominate life on our planet, and the question of how they interact with the environment and larger organisms remains one of the most important mysteries: How do complex, modern ecosystems such as the ocean work? "Although we understand with some certainty that the climate is changing, 


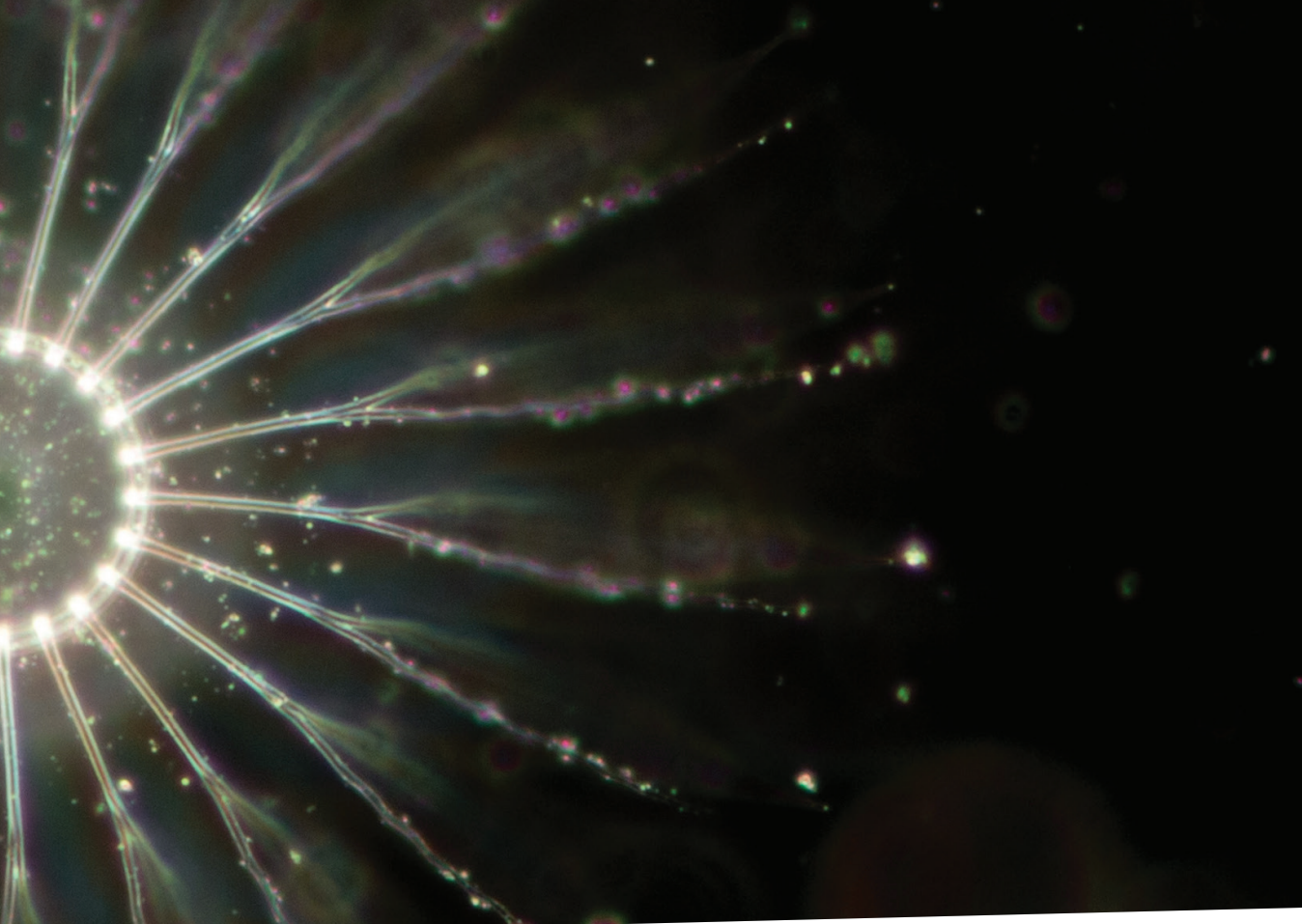

and that the oceans of the future will likely be warmer, more acidic and contain less oxygen," says Marc, "it's very difficult to make specific predictions about the impacts of climate change, especially on larger organisms such as fish, whales and humans." Doliolids connect microbes with larger organisms, so knowing their role in marine foods webs will help marine scientists - and us - understand and prepare for the consequences of future ocean changes.

\section{HOW DOES MARC'S}

\section{TEAM STUDY DOLIOLIDS?}

Marc and his colleagues have been studying doliolids in the ocean and in the lab, but it's not easy. Doliolids are small, transparent, delicate creatures, so they're hard to count, catch and grow. Indeed, doliolids are so delicate that standard nets damage them. Marc uses a special plankton net to capture doliolids (take a look at the photo on the next page).

Interestingly, other researchers are studying doliolids without even capturing them.

Rather, they're taking videos of these delicate creatures in the ocean, and processing these images using powerful computer analysis tools. "I think these tools will eventually lead to exciting new discoveries about doliolids and the many other types of gelatinous organisms that are too delicate to capture using nets," says Marc.

\section{HOW DOES MARC'S TEAM}

\section{STUDY WHAT DOLIOLIDS EAT?}

Inside their little, barrel-shaped bodies, doliolids catch food using a fine mesh that they create out of sticky mucus. The doliolids filter water through this mesh, capturing particles that can be as small as bacteria or as large as their mouth. Scientists think that the mucus is best suited to catching algaesized particles.

In his lab, Marc first extracts all the DNA from a doliolid and then removes the DNA belonging to doliolids. This means that he's left with DNA that he presumes comes from the food they ate (or any parasites that may have come along for the ride). Using this technique, Marc has found that doliolids actually eat a lot of different foods, but they can sometimes be picky about what they eat! "We didn't expect this," he says. "It just adds even more mystery to the question of what they eat. As Albert Einstein is credited with saying: 'the hallmark of good research is that it raises more questions than it answers'. This is certainly the case with doliolids."

\section{WHAT EATS DOLIOLIDS?}

It's thought that lots of larger organisms eat doliolids, but scientists aren't exactly sure which ones. Some have suggested that important fish species such as plaice, tuna and marlin eat doliolids at some point during their lifespan, most likely when they're larvae or juvenile (i.e. very young).

Excitingly, Marc's studies on the continental shelf of the South Atlantic Bight, which runs along the US Atlantic coastline from Cape Hatteras in North Carolina to Cape Canaveral in Florida, has shed some light on this mystery: His team found that doliolids in this region were eaten by small jelly fish-like animals called hydromedusae.

\section{HOW WILL CLIMATE \\ CHANGE IMPACT DOLIOLIDS?}

We know that doliolid populations vary depending on the amount of food that's available in the ocean. And the amount of food available to doliolids depends on how many nutrients (mainly nitrogen) make it from the deep ocean

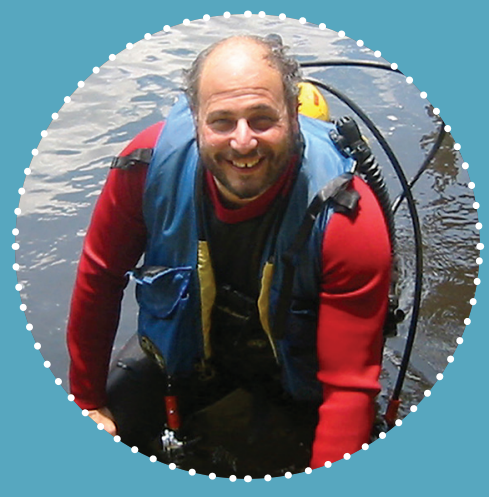

\section{MARC FRISGHER}

Professor of Oceanography Skidaway Institute of Oceanography University of Georgia ..........

FIELD OF RESEARCH Biological Oceanography

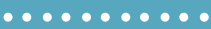

\section{RESEARCH PROJECT}

Marc and his team are studying doliolids and the food they eat. Through his work, Marc hopes to understand the critical role doliolids play in the marine ecosystem, and how their existence is threatened by climate change.

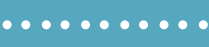

\section{FUNDERS}

FUNDERS: The US National Science Foundation, the US National Oceanic and Atmospheric Administration, the US Department of Energy, and various other US State and National funding agencies.

onto continental shelf, where doliolids are found. Currents push nutrient-rich water from the deep ocean onto the continental shelf, which allows algae to grow and, ultimately, provides doliolids with food.

A lot of different factors affect these currents, including wind patterns. Scientists expect climate change to affect wind patterns, but they're still uncertain about how much this will alter the availability of food for doliolids. Scientists also don't know whether other climate change impacts, such as higher temperatures, less oxygen and more acid in the oceans, will affect doliolids.

This is why the work of biological oceanographers such as Marc and his team is incredibly important: Knowing what role doliolids play in food webs and the ocean ecosystem will help scientists to find a deeper understanding of the impacts of climate change - and we need more marine scientists like you to help! 


\section{ABOUT OCEANOGRAPHY}

oceanographers can choose to work in a wid
oceanography is a broad field, meaning

range of different topics: marine life and ecosystems, plate tectonics, the geology of the seafloor, and the chemical and physical properties of the ocean.

Marc is a biological oceanographer and has been studying the oceans for over 30 years. We ask him why it's important to study oceanography.
"The oceans are the life support system of our planet. Every other breath of air we breathe was produced by phytoplankton, the microscopic plants that grow in the ocean. The ocean serves as the primary thermostat for our climate. It's the biggest contributor to the planetary water cycle: It impacts where and when it rains, floods or dries out. The ocean generates massive storms and it sustains us. And yet, the ocean is remarkably understudied and, in many parts, still unexplored.
Most species on Earth reside in the ocean, many of them remaining to be discovered. In all likelihood, life originated in the ocean. Rather than argue "why" study marine sciences, I would argue that we must study the ocean and all the life in it. I believe that the survival of humanity depends on it."

\section{OPPORTUNITIES IN OGEANOGRAPHY}

- Many organisations in the US (https://www.marinecareers.net/ summer) and around the world (https://www.teensummercamps. com/collections/marine-biology/europe) host summer programmes

that take high school students out onto the ocean to learn about what it's like to be an oceanographer

- World Oceans Day on 8th June has a youth advisory council and a youth for the ocean network ... get involved! https://www.worldoceansday.org/

- There are so many opportunities open to graduates with a marine sciences degree. You can conduct research out in the "field" (the water), in a laboratory or both. You can teach at a university or work in a museum, aquarium or zoo. You can conduct research for the government or work for an environmental non-profit organisation, such as a marine animal rescue facility. The NOAA's National Marine Fisheries Service provides a good overview, for example, you don't need a PhD to work on marine biology experiments, but a PhD will allow you to run your own expeditions and come up with your own experiments

- According to the US Bureau of Labor and Statistics, the average university-employed marine scientist makes about $\$ 98,560$ a year, but the salary can range widely depending on your education and experience

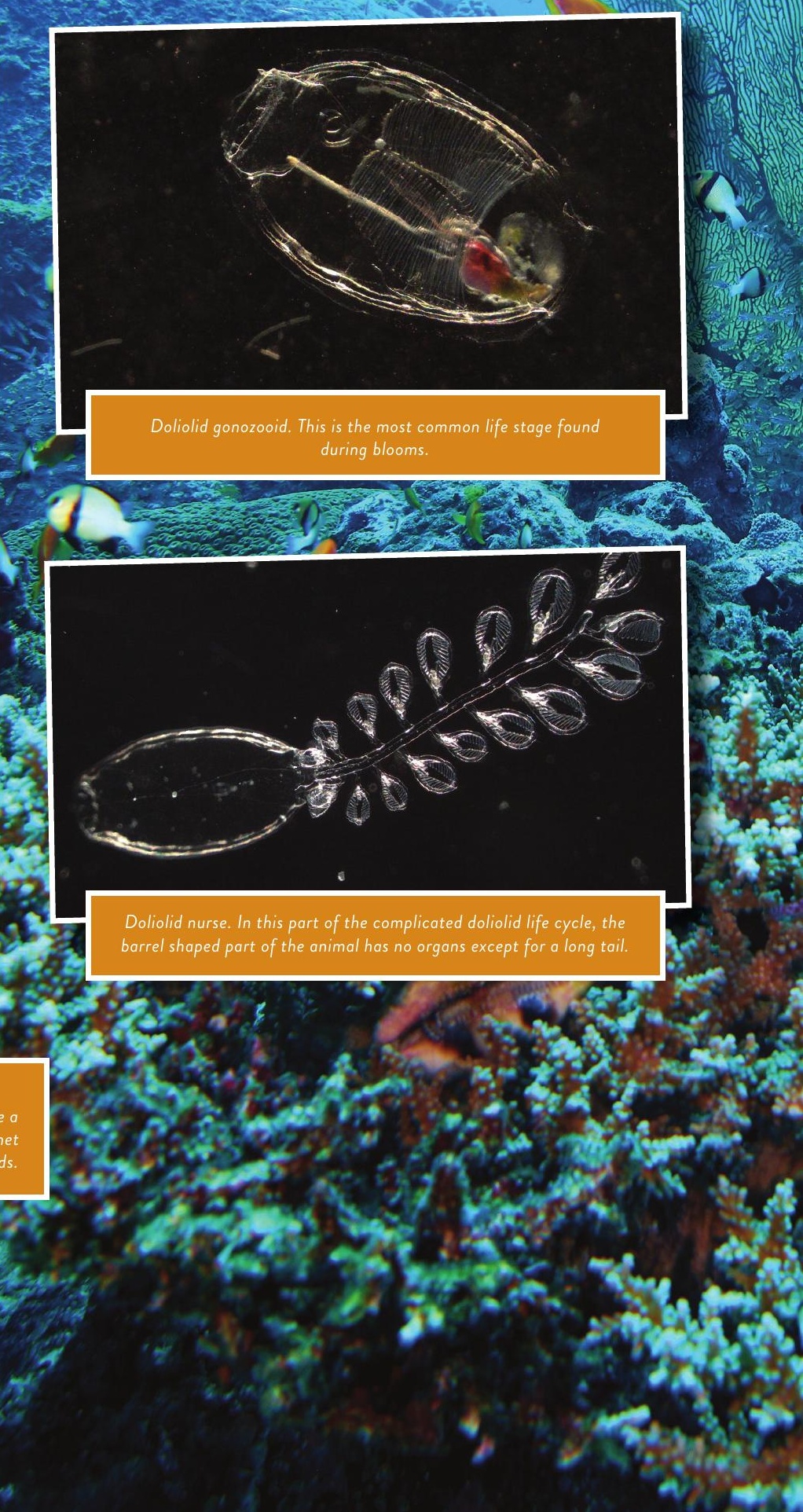


